\title{
Aboriginality and historical consciousness: Bernard O'Dowd and the creation of an Australian national imaginary
}

\author{
Frank Bongiorno
}

If he is not a poet, he has in him the elements of poetry...

He has many very good qualities and many very bad ones; and in the contrarieties of his mental constitution there is much to remind us of the peculiarities of the people of our own race.

R Brough Smyth, The Aborigines of Victoria (1878) xviii

WHILE Senator Keating was discoursing on Wednesday at the Australian Natives' Association ${ }^{1}$ Conference at Bairnsdale, on the advantages of techrical education to the Australian natives, an odd figure, garbed in a military uniform, appeared at the doorway of the hall. Though not a member of the association, the visitor was undoubtedly an Australian native. A huge medal, hanging from a string encircling his swarthy neck, set forth that he was of Royal birth, being no other than 'King Bobbie of Bunderwall.' With many broad and amiable grins, and much scraping and bowing, he advanced into the hall. A great roar of laughter and some cheering greeted his appearance, and the president ordered his removal. As, however, he respectfully uncovered his head, and evinced much interest in the proceedings, he was accommodated with a seat, and allowed to listen to the speeches of his white compatriots.

Argus, quoted in Steele Rudd's Magazine, November 1905, p. 1009

Here, and here only in an age of iron,

The dreamers are proved right;

No armies underlie these rolling fields,

No lost loves haunt the night,

Nor can the farmer, turning with his spade,

Bring shard or helm to light.

Chris Wallace-Crabbe, 'Terra Australis', in Selected Poems Melbourne (1973) p. 39

1. The Australian Natives Association was a nationalist benefit society established in Melbourne in 1871. Its membership was restricted to (white) men born in Australia. The term 'native' was frequently used in reference to such men (and women) in order to distinguish them from immigrants. 
Australian cultural historians have recently given considerable attention to the ways in which some white Australians have appropriated and incorporated Aboriginal culture in their efforts 'to assemble a national identity'. ${ }^{2}$ In much twentieth century Australian historical writing, the development of nationhood has been understood as a process of maturation or 'growing up', in which colonists come to terms with their environment and define themselves in relation to the mother country. Until recently, white Australian images of Aboriginal culture have not figured prominently in these accounts. Within the tradition of imperial history, there was an emphasis on the ways in which colonists reconciled their British imperial identity with a sense of being colonial and therefore at the margins; in radical nationalist writing, the stress was on the ways in which Australians differentiated themselves from the parent culture. ${ }^{3}$ Indeed, it is only in recent times, as historians have embraced a more critical understanding of the nation-state, that the manner in which white Australian myth-makers have appropriated Aboriginal culture has entered discussion of Australian national identity. ${ }^{4}$ This revisionism has occurred as part of a larger post-colonial awareness of white Australians' status as colonisers and even invaders, while the ubiquity of images of Aboriginality in contemporary representations of the nation has also kindled interest in this issue. The invention and promotion of such images involve an appropriation of the Aboriginal presence in a manner that 'permits the Australian national imaginary to claim certain critical and valuable aspects of "the Other" as essentially part of itself". ${ }^{5}$ As Denis Byrne has shown, this project has as its end the production of a 'deep nation' based on the assimilation of 'a "detached" version of Aboriginal culture' derived from the 'natural history, ethnology, antiquarianism and archaeology' of the colonisers. ${ }^{6}$ Aboriginality becomes a constituent in a larger complex of sounds and images that signify Australian national identity, a process in which some Aboriginal people might now sometimes be complicit, but which they cannot control.

This process did not begin yesterday; it has a history. Tom Griffiths has recently drawn attention to what he calls "European rituals of place or "land rites", which 'aimed to secure the land emotionally and spiritually for the settler society'. He argues that these 'land rites were most overt during the early decades of the twentieth century, the very period when acknowledgement of the violence and illegitimacy of the European invasion of Australia was most strongly suppressed and denied'. ${ }^{7}$ This article is a study of one writer's contribution to European 'Iand rites'. Bernard O'Dowd's activities as a nationalist poet and radical intellectual have already received considerable attention, but there has been little recognition in this work of his attitude to Aborigines, nor of the connections between his attitudes to race and his nationalism. This is somewhat surprising in view of $O^{\prime}$ Dowd's well known opposition to the White Australia policy. ${ }^{8}$ Indeed, O'Dowd's hostility to racial discrimination poses peculiar problems for an

2. Tsokhas 1998: 230-47. See also Scates 1997: 35-49; Hamilton 1990: 14-35; Sellick 1995: 102-15; Byme 1996: 82-106; Lattas 1992: 45-58; McLean 1998.

3. Macintyre 1998: 339-40.

4. For an excellent overview of these themes, see Attwood 1992.

5. Hamilton 1990: 18.

6. Byrne 1996: 99 .

7. Griffiths 1996a: 151.

8. Osborne 1978: 112-28. 
understanding of his nationalism, as so much historical writing on Australian nationalism has assumed 'racism' (however defined) to be its corollary. 9

\section{National history, landscape and the 'native'}

Bernard Patrick O'Dowd (1866-1953) was born at Beaufort in Victoria and raised as a Catholic by Irish-born parents, who immersed their son in the Celtic ballads, myths and legends of their ancestors. It was an upbringing calculated to foster an awareness of both the power of myths and legends, and of the dearth of 'magic' in conventional colonial attitudes to the Australian landscape, at least in comparison with the rich cultural capital he had inherited from his parents. ${ }^{10}$ In this respect, there are striking similarities between O'Dowd and the New Zealand public servant and writer Edward Tregear. In a biography of Tregear, KR Howe describes his subject as 'a sensitive and highly imaginative boy who steeped himself in medieval legend and Celtic mythology'. ${ }^{11}$ This could just as easily be a description of a youthful O'Dowd. Both men were involved in the freethought movements in their respective countries, and both joined the Theosophical Society, suggesting a common interest in comparative religion and mythology. ${ }^{12}$ Tregear is remembered today for his contribution as a public servant to New Zealand's state experiments and his investigations of the origins of the Maori, whom he believed to be descended from the Aryans of India. Howe argues that through his writings on this latter subject, Tregear aimed to give 'meaning and identity to the past and present of a new land': ${ }^{\prime 3}$

With his 'discovery' that Maori were Aryans, Tregear's New Zealand was no longer 'songless' - that hostile barren land without history which once he had peopled with princes, kings and deities inspired by classical and Arthurian legend ... His adopted country now had an imaginative and historical landscape ... Tregear filled a desolate land with people, history, mythology and culture that he could understand, relate to, and willingly embrace. It was a feat of intellectual occupation, possession and control.

Tregear had 'figuratively domesticated a whole country and its original inhabitants', making of New Zealand 'his emotional, spiritual and cultural home' ${ }^{14}$

O'Dowd, as we shall see, was engaged in a similar act of knowing and possessing. According to his biographers, his reading of the work of Baldwin Spencer and FJ Gillen on the central Australian Aborigines and RB Smyth's The Aborigines of Victoria (1878) helped to nourish an imagination preoccupied with the problems of living in a 'new country' (new, that is, to European colonists) that also had a much longer natural and human history. ${ }^{15}$ Indeed, he considered the writings of Spencer and Gillen 'as signifi-

9. McQueen 1985: 29.

10. See Kright 1991: 13-24. On this question, Baldwin Spencer's biographers emphasise the liberal politics and Irish background and self-image of Frank Gillen. The connections in the Australasian colonies between Celtic identity, radical and liberal politics, cultural nationalism and anthropological interests would repay a researcher's attention. O'Dowd, like Gillen, was an avid supporter of Home Rule for Ireland. See Mulvaney and Calaby 1985: 162-3, 175.

11. Howe 1991: 13 .

12. Howe 1991: 34,62

13. Howe 1991: 64 .

14. Howe 1991: 52.

15. Kennedy and Palmer 1954: 77, 99. 
cant to the philosopher and as inspiring to the poet as they are important to the scientific man', 16 while Smyth, another favourite of O'Dowd, had hinted at a common Aryan heritage for black and white Australians, emphasising the similarities between 'the legends of the natives' and 'the folk-lore of the Aryan or Indo-European race'. ${ }^{17}$ There was a powerful cultural nationalism at the heart of both Tregear's and O'Dowd's activities, a desire to show that '[t]he antipodean environment and both its old and new societies were fit subjects in themselves for artistic expression' ${ }^{\prime 18}$ The attempt to place the 'native' in world history was an integral part of this project.

Brian Elliott, virtually alone among literary critics and cultural historians, has noticed O'Dowd's appropriation of Aboriginal culture (or at least Aboriginal culture as it was represented in the writings of Spencer and Gillen), and stresses his pioneering role in the use of the concept of the 'Alcheringa' (or 'dream times'). ${ }^{19}$ In this respect, he portrays O'Dowd as an ancestor of the Jindyworobak poets of the 1930s-1950s, who sought to use Aboriginal culture to create an Australian poetry infused with 'environmental values'. Elliott, however, who was himself a Jindyworobak, is committed to the idea that the Aborigines and the Jindyworobaks, in their relationship to the land, shared in 'a mystical experience ... which may be designated for both the white and the black, though with different implications, as Australian site-magic': there was 'sharing, and therefore universality'. ${ }^{20}$ As David Carter has remarked, this understanding of the relationship between Aborigines, Europeans and the land has been influential in recent representations of the nation, but it 'carries its own form of blindness ... Aboriginality is performed for the benefit of non-Aboriginal Australia' ${ }^{21}$

O'Dowd's principal concern was the construction of a national culture for the settler colonies rather than the understanding of Aboriginal society as a living presence. He appeared to accept the idea common among his (European) contemporaries that it was the desert Aborigines, those portrayed by Spencer and Gillen and assumed to be primitive and uncontaminated by civilisation, who were now ' $r e a$ ' $^{\prime}$ Aborigines. This view, which often involved a dismissal of the cultures of so-called 'degraded blacks' living in more closely settled areas, depended on an acceptance of Social Darwinism. There is, moreover, no evidence that $\mathrm{O}^{\prime}$ Dowd had any interest in regional cultural differences: such recognition would have been foreign to his purposes in appropriating Aboriginal culture. Yet Aboriginal people were a living presence in the Ballarat district in which Bernard grew up. Victor Kennedy and Nettie Palmer remark in their authorised biography that young Bernard was frightened by 'the handful of blacks who wandered into the settlement' of Beaufort 'with their dogs and strange weapons'. Later they supposedly 'drew him into their circle', and he brought water to their camp from the family home. Their 'ancient chief', whom Bernard remembered affectionately as one 'King Billy', called him 'Yarrum-Yarrum' (little water-carrier). ${ }^{22}$ Yet, like many of his

16. Tocsin, 7 September 1899.

17. Smyth 1972: 1x, lxvii.

18. Howe 1991: 67; see also McLean 1998: 9.

19. Elliott 1979: xxi-xxiii.

20. Elliott 1979: xxx; Elliott 1977: 43. See also McLean 1998: 95-8, 114-19.

21. Carter 1994: 10-11.

22. Kennedy and Palmer 1954: 7, 9-10. 
contemporaries, it was to the interior that Bernard later looked for an authentic Aboriginality.

O'Dowd's problem was how imaginatively to possess a landscape which he knew had been previously possessed (both imaginatively and otherwise) by Aboriginal people. As we shall see, this was one of the aims of his long poem, The Bush, in which O'Dowd's ideal nation was inseparable as a concept from the landscape which sustained it' ${ }^{23}$ Anthony Smith has seen this project of attaching a poetic to the landscape as a crucial dimension of the process of nation formation. Intellectuals, he argues, create "new "maps" and "moralities" through the uses of landscape and golden ages of a rediscovered and reconstructed communal past'. One of their typical modes of behaviour is the creation of 'poetic spaces', the endowment of a particular physical entity 'with poetic and historical connotations, or rather with an historical poetry'. Educatorintellectuals seek to turn 'bare nature into poetic history'. This might also involve the transformation of particular historical features (he cites Stonehenge as an example) into symbols of nationality. ${ }^{24}$ Uluru has been pressed into the service of Australian national identity in this manner over the last few decades; and, since the coming of the Europeans to Australia, both the bush and the desert have served the myth-making purposes of nationalist writers and intellectuals.

O'Dowd turned to both bush and desert in his effort to create a national imaginary. As Roslynn D Haynes has recently shown, by the 1890s the desert 'had succeeded the Bush as the actual frontier' in Australia, although it suffered some serious disadvantages as a potential symbol of national identity, being 'neither profitable nor picturesque' in the eyes of most colonists. ${ }^{25}$ O'Dowd, however, always on the lookout for materials with which to construct an Australian pantheon, invested great symbolic significance in Chambers Pillar, a prominent central Australian rock formation, where he claimed to commune (in spirit) : with his 'Comrade' and 'Comforter' (apparently a woman living in Western Australia):

When She and I meet (almost nightly, indeed in holiday times and on north-wind days almost daily also) it is usually in the vicinity of Chambers' Pillar in Centralia: for not only is it a convenient half-way house in our separating desert, but there is something so sacredly and intimately Australian in the virgin solitude, something so unspoilt and unspoilable in the native aura of the place, that here surely is the Olympus of the Australian dispensation, where the gods we make by our virtues and our powers shall abide and cherish us for ever. ${ }^{26}$

O'Dowd never actually visited the place, but Chambers Pillar featured in The report of the Horn Scientific Expedition to central Australia (1896), ${ }^{27}$ which was edited by Melbourne University biologist Baldwin Spencer and read by O'Dowd. (It was apparentiy

23. Elliott 1967: 190, 196.

24. Smith 1989: 340, 356-7.

25. Haynes 1998: 144.

26. O'Dowd, 'Morgana Mine and Other Realities', in O'Dowd 1944: 267. It was first published in 1907.

27. For details of the Horn Expedition of 1894, see Mulvaney and Calaby 1985; Morton and Mulvaney 1996. The expedition has now been widely recognised as an important moment in white Australian perceptions of both central Australia and the Aboriginal people. It was concerned with geology, biology and anthropology. 
Alfred Deakin who arranged for O'Dowd to have access to the Parliamentary Library's copy.) ${ }^{28}$ There is a photograph of the formation in the anthropology volume (Pt IV). In Spencer's narrative in the introductory volume, 'Through Larapinta Land', the importance of the pillar to the local Aborigines attracts some comment:

The blacks have a rather curious myth to account for the origin of the pillar. They say that in what they call the Alcheringa (or as Mr. Gillen appropriately renders it the 'dream times'), a certain noted warrior journeyed to the east and killing with his big stone knife all the men, he seized the women and brought them back with him to his own country. Camping for the night on this spot he and the women were transformed into stone, and it is his body which now forms the pillar, whilst the women were fashioned into the fantastic peaks grouped together to form what is now known as Castle Hill, a mile away to the north. ${ }^{29}$

This was the first mention of the 'Alcheringa' (and of 'dream times') in the report, and, indeed, 'in European writings about central Australia'. It was also, according to Barry Hill, an important moment in European understanding of 'the fundamental connections between place and human settlement in Australia', in its notion of a 'body' being a 'pillar' ${ }^{30}$ The passage evidently had a considerable impact on $O^{\prime}$ Dowd's imagination, inclined, as it was, towards any 'intimation of a local classical past preceding or congruent with the Aboriginal presence' ${ }^{31}$ Chambers Pillar becomes Olympus; the Alcheringa, an Australian golden age. In 1947 O'Dowd made large claims about his own role in popularising the term 'Alcheringa':

I think I was the first to put 'Alcheringa' into our literature \& have no doubt, aesthetically, that mine is the apt pronunciation ... My house in Moonee Ponds was 'Alcheringa', \& thus pronounced by a myriad postmen \&c, often before the new 'poets' were born. As it's our local Garden of Eden, Saturnian age \&c. \&c. it deserves a worthy pronunciation, \& I claim that, both by analogy with 'churinga' \& similar words, and by usage for a $1 / 4$ century anyway, \& by the chrism of dignity mine fills the bill. ${ }^{32}$

A striking feature of this passage is O'Dowd's assumption that the term is ripe for appropriation by white Australian writers: the 'Alcheringa' is 'our local Garden of Eden' (my emphasis) and the manner in which the word is pronounced should be decided by reference to considerations defined by European Australians, who he assumes have acquired ownership of the term and concept via his own pioneering effort. O'Dowd's naming of his own home 'Alcheringa' dramatises this sense of ownership, metaphorically domesticating Aboriginality for the use of suburban Australia.

In a study of the place of the Dreamtime in Australian anthropology and culture, Patrick Wolfe has argued that 'the Dreaming complex was an invention of the anthropologists' own culture'. In his view, the growing popularity of the concept both inside and outside the anthropological profession in the twentieth century can be explained by its usefulness to the colonising project of the white settler society. The concept pio-

28. O'Dowd to N Palmer, 31 December 1947, Palmer Papers, National Library of Australia (NLA) MS 1174/1/7326.

29. Spencer 1994: 50 .

30. Hill 1996: 32.

31. Griffiths 1996: 36.

32. O'Dowd to N Palmer, 31 December 1947, Paimer Papers, NLA MS 1174/1/7326. 
neered by Spencer and Gillen 'subordinated dreaming savages to the level of animal nature'. ${ }^{33}$ This view has been more recently challenged by Howard Morphy, who emphasises the disjunctures between the anthropological work of Spencer and Gillen and the colonising process. Although Spencer and Gillen's perspective was shaped by evolutionary biology, '[t]he vividness of their data and the detail of their accounts subtly changed the nature of the discourse away from Aborigines as exemplars of early stages of human evolution to understanding Aboriginal religion in its own right'. Their findings in many respects 'contradicted the evolutionary framework that underpinned their research and challenged the treatment of Aborigines'. ${ }^{34}$

As we shall see, a similar ambivalence about the Aborigines and the colonising project enters O'Dowd's writing in the 1890 s, prompted partly by his reading of anthropological work such as that of Spencer and Gillen. For O'Dowd, the Aborigines enter 'national consciousness only when appropriated and integrated with the culture and history of the coloniser' ${ }^{35}$ Far from being part of the national culture in their own right, they are a mystical stone-age leftover, or 'living fossils'. O'Dowd would not have needed to read the report of the Horn Expedition to formulate such an understanding, but that publication probably reinforced attitudes already held. In his Introduction to the report, the expedition's sponsor, WA Horn, described the central Australian Aborigine as 'the living representative of a stone age' whose 'origin and history' were 'lost in the gloomy mists of the past'. ${ }^{36}$ As Griffiths comments, the expedition 'revealed the richness of central Australian Aboriginal culture only to deny it in the service of Social Darwinism'. O'Dowd, in every sense a child of the age of Darwin, shared the evolutionary perspective of the Horn expeditioners, and, as his most famous poem ('Australia') indicates, like them he was attracted to the idea of Australia as a kind of 'continental museum where the past was made present in nature $:^{37}$

The cenotaphs of species dead elsewhere

That in your limits leap and swim and fly,

Or trail uncanny harp-strings from your trees ...

The 'primitive' Aboriginal people were easily assimilated into this perspective.

The influence of the report of the Horn Expedition is registered elsewhere in O'Dowd's writings, as is his desire to domesticate Aboriginality. In an 1897 article with the title 'The Dream Times', published in the Australian Natives Association's Advance Australia, O'Dowd ridiculed the notion that Australians should confine themselves to the construction of 'as decent a makeshift antiquity as possible for ordinary domestic purposes'. Australians had in their culture 'the elements ... of Romance':

As inevitably as our backblocksmen will make our central deserts blossom as the rose, will our embryonic historians, mythologists, anthropologists, and poets teem the seeming blank of our past with strange sociologies and politics, with themes, powers, and dominations undreamt of by the plagiarising thaumaturgists of European Art. ${ }^{38}$

33. Wolfe 1991: 199, 206.

34. Morphy 1996: 185, 187. See also Attwood 1996: 114.

35. Tsokhas 1998: 246.

36. Horn 1994: ix.

37. Griffiths 1996b: 16-17. 
O'Dowd's tendency to see himself as both a participant in and a commentator on this process of invention has caused confusion among some literary critics. This dual role is evident in those early stanzas of The Bush that have so annoyed even admirers of $\mathrm{O}^{\prime}$ Dowd and the poem. These were filled with references to figures associated with Australian politics, art and literature - many of them friends of O'Dowd - whose identities and activities are, sometimes with considerable skill and humour, conflated with people, places and events from the history and mythologies of other lands. So we find Walter Murdoch as 'Zenobia's counsellor', future scholars restoring Australia's 'prehistoric drama' from Louis Esson's 'The Woman Tamer', and references to 'Longmore-featured Gracchi' and the 'Greek-browed Higinbotham'. Baldwin 'Spencer sails from Alcheringa bringing/Intaglios, totems and Books of the Dead', while 'Herod's daughter sools her 'morning daily'/On John the Baptist by the Yarra Bank'. The poet sees these Australians as contributing to a future national historical consciousness, for their young nation 'is the whole world's legatee', 'a prophecy to be fulfilled', 'the scroll on which we are to write/Mythologies our own and epics new'. Meanwhile, O'Dowd erases the Aboriginal presence from the country, accepting the legal fiction of terra nullius so that Australia becomes 'The Sleeping Beauty of the World's desire' who (in Haynes's words) is 'passively awaiting the arrival of its princely (and pre-ordained) colonists' ${ }^{39}$ Australia is assimilated to a European utopian vision, while 'The Bush' moulds for colonists 'white ideals to obey'.

Yet there is ambivalence: total obliteration of the Aboriginal presence is not feasible, if only because the Aborigines are required to contribute to the Gothic atmosphere of certain sections of the poem ('Spectral a tribe round poisoned rations shrieks'). The Aborigines thus become a part of the landscape itself, rather than a living presence in the coming ration; and, as if to dramatise the point, the stanza (20) that mentions the shrieking tribe also contains references to Adam Lindsay Gordon, Robert O'Hara Burke, Ludwig Leichhardt and Barcroft Boake, all of whom either killed themselves or perished in the Australian desert. O'Dowd, moreover, adheres to the lost race convention which, as several cultural historians have shown, was common in much popular writing of the turn of the century. ${ }^{40}$ It eliminated any real possibility of an empathetic understanding of Aboriginal culture: they were, after all, probably remnants of some lost white tribe, paying the price for their fathers' sins.

O'Dowd seems to have viewed his own role as both that of national myth-maker - the kind of educator-intellectual to whom Smith has drawn attention ${ }^{41}$ - and also, as his 'The Dream Times' article suggests, as a commentator on the business of mythmaking. He understood that nations are, to some extent, made in the minds of men and women. Consequently, he supported organisations that defined their role as the fostering of an Australian historical consciousness. Although he was unable to attend the first meeting of the Royal Historical Society of Victoria in 1909, he was in entire sympathy with aims - indeed, considered establishment of some such means of preserving the raw materials of our future noble historical tapestry a civic duty on Australians'. ${ }^{42} \mathrm{He}$

\footnotetext{
38. Advance Australia, 1 June 1897.

39. Haynes 1998: 5.

40. Docker 1991; Dixon 1995; Haynes 1998; Albinski 1987; Healy 1978b. See also McLean 1998: 51.

41. Smith 1989: 356.
} 
was also a contributor to Isaac Selby's Old Pioneers Memorial Fund, which campaigned in the early 1920s - unsuccessfully - to preserve the Old Melbourne Cemetery from destruction and have a war memorial built on the site. ${ }^{43}$ As Griffiths has shown, Selby appealed to the court of historical authenticity in his effort to preserve the material remains of the colonial past from the crude claims of modern commerce, an argument that $O^{\prime}$ Dowd, as a socialist, would have found attractive. ${ }^{44}$

\section{Lemuria, theosophy and Aboriginality}

For O'Dowd, one way in which this romantic national consciousness - an 'indigenous' sense of the past - would be created was by connecting the history of the Australian continent and the Aboriginal people to the history of humanity. ${ }^{45}$ lndeed, he saw in Aboriginal cultural practices, myths and legends circumstantial evidence of a secret history of a lost white civilisation of central Australia. His discussion of the Aborigines is connected to a Lemurian myth that historians have seen as characteristic of the 1890s in Australia (and elsewhere). ${ }^{46}$ Lemuria was the name which PL Sclater, a zoologist, gave to a lost continent that had once supposedly extended from South-East Asia nearly to Africa. As the Mosaic chronology became widely discredited in the second half of the nineteenth century, there was considerable room for speculation about lost continents and 'primitive' peoples. ${ }^{47}$ In this connection, $O^{\prime}$ Dowd might have been influenced by the ideas of HP Blavatsky, one of the founders of theosophy: Bernard had been associated with the Society, sometimes as a member, since the $1890 \mathrm{~s} .{ }^{48}$ Jill Roe has pointed to Blavatsky's role in popularising the concept of Lemuria through her writings such as The Secret Doctrine, although it is likely that $\mathrm{O}^{\prime}$ Dowd would already have encountered the idea in the work of German biologist Ernst Haeckel, who regarded Lemuria as 'the probable cradle of the human race'.$^{49}$ Blavatsky believed that Australia had once been 'an inland region on the Mother Continent'. This view gave Australia 'profound importance' in world history. (No wonder it appealed to a cultural nationalist such as O'Dowd!) Blavatsky's view of history was essentially cyclical, and the Lemurians were the third of five root-races that had thus far featured in world history. They were originally 'bi-sexual', and the most mysterious of the root-races: theirs was 'a golden age of elemental religion'. 50

42. O'Dowd to AW Grieg, 19 May 1909, Historical Society of Victoria, Correspondence [2 April $1909-17$ June 1910], Box 35/10(a), Royal Historical Society of Victoria Collection, also quoted in Griffiths 1996a: 208.

43. Report of the Old Pioneers Memorial Fund, 5 July 1926 (Isaac Selby, Secretary), in Isaac Selby, Memorandum Book, SN 18, MS 694, Royal Historical Society of Victoria Collection. O'Dowd is in the list of subscribers. He gave $£ 1$. He is also in the list of subscribers for 1932 as having donated one guinea.

44. Griffiths 1996a: 161-5.

45. Healy $1978 \mathrm{~b}: 316$.

46. Spence 1932.

47. Healy 1978b; Griffiths 1996a: 43-4.

48. Samuel Studd (Honorary Secretary, Melbourne Theosophical Society) to O'Dowd, 12 June 1899, HH Pearce Papers, NLA MS 2765/9/1/2. O'Dowd had failed to pay his dues.

49. Roe 1986: 76-80; Spence 1932: 137.

50. Roe 1986: 78; Spence 1932: 86-90. 
For Blavatsky, the Australian Aborigines - or at least some of them - were descended from the Lemurians:

The Secret Doctrine teaches that the specific unity of mankind is not without exceptions even now. For there are ... descendants of these half-animal tribes or races, both of remote Lemurian and Lemuro-Atlantean origin. The world knows them as Tasmanians (now extinct) [and] Australians.

This absurd perspective, which as Jill Roe has shown drew on Social Darwinist ideas for occult purposes, could offer powerful support for colonisation and dispossession. ${ }^{51}$ The Australian descendants of the Lemurians, after all, in Blavatsky's view belonged to 'a very low sub-race, begotten originally of animals, of monsters, whose very fossils are now resting miles under the sea floors'. She claimed that they had existed for thousands of years 'in an environment strongly subjected to the law of retardation', and so had become 'degraded men'. The Aborigines, she declared, were 'the descendants of those, who, instead of vivifying the spark dropped into them by the 'Flames', extinguished it by long generations of bestiality'. They were thus not merely a doomed race; Blavatsky also denied the Aborigines a full measure of humanity, attributing to them a spurious hybrid quality - part animal, part human. Consequently, she believed Aborigines unfit 'to occupy the forms of men destined for incarnation in higher intellectual Races'. Indeed, their passing, for her, seemed to provide proof of Karma, since the races whose time was up were being destroyed all over the globe. Esoteric philosophy regarded them as 'the senile representatives of lost archaic nations'. 'It is inaccurate', Blavatsky asserted, 'to maintain that the extinction of a lower race is invariably due to cruelties or abuses perpetrated by colonists'. The ancient Australian continent could 'produce no new forms, unless helped by new and fresh races, and artificial cultivation and breeding ${ }^{\prime} 52$

This type of speculation, which spawned a body of popular literature considerable in size if not in quality, appealed to some white Australians who desired to furnish themselves with a history which had happened on their own continent; theirs was an effort to find deeper roots in the soil, to resolve the problem of being colonial by inventing an ancient history for this continent in which the whites had a part. Yet as John Docker has remarked, Lemuria's antiquity also

allows for ... the discomforting thought that history is not necessarily a narrative of linear progress ... nations and societies wax and wane in strength and power, they rise and fall, even the mightiest of them, often ending, after some kind of cataclysm, in disappearance or barbarism - when they have to start all over again'. ${ }^{53}$

We cannot be sure of the extent to which O'Dowd took theosophical speculation about Lemuria on board, but it did provide a part of the framework he used to understand the Australian Aborigines and their place in world history. He remarked that

[M]any things tend to confirm our instinct of a past ... The singular relics of Easter Island ... taken in conjunction with the Darwinian theory of coral reefs, and the coralline surroundings of so much of our coast line, point to a connection between Australia and some strange civilisation that has weirdly flitted into temporary

51. Roe 1986: 115.

52. Blavatsky 1993, vol. II: $162,195-7,318,779-80$.

53. Docker 1991: 222. 
oblivion. The customs of our aboriginal tribes often hark us back to some strangely-wise statesman or divine prophet who, unassisted by even an alphabet, winged his devices for securing the greatest good of his race through countless generations of as hopeless brain material as ever this world has owned. The legends of these peoples are full of ... startling suggestions of Caucasian - or at least high-grade Turanian - influences ... 54

Although the theory that Aboriginal people and Caucasians were related had some scientific support at this time, the implication here is that the complexity of Aboriginal society is only explicable if we can find evidence of the influence of the so-called higher races. One is reminded here of the explorer George Grey's belief that Aboriginal rock paintings he encountered in north-west Australia could not 'have been executed by a self-taught savage', and so might have been painted by an alien race. ${ }^{55} \mathrm{O}^{\prime}$ Dowd invents an ancient history of Australia that does not allow Aborigines to have their own history, although one cannot help wondering how seriously he intended readers to take his suggestion that the Carthaginian,

degraded by a plutocratic commercialism brutally like our own, and devitalised by the sensuous excesses of the cults of Aphrodite Pandemos, or the maniac mutilations of Adonaic mysticism, is now wandering a craven savage over Centralian sandhills, practising alternately, as in a hideous nightmare of the past, the same excesses and the same mutilations. ${ }^{56}$

Yet the idea that the Aborigines were somehow expiating the sins of some past great civilisation occurs elsewhere in O'Dowd's writing. It is a testament to the importance of the lost race convention for him, as well as of the strength of the Hebraic tradition of the desert as 'not only a perpetual reminder of the Fall' but also 'a warning that disobedience to God will perpetuate the curse' ${ }^{57}$ The passage quoted above, moreover, reveals O'Dowd's attachment to the doctrine of reincarnation, which was central to theosophical belief.

O'Dowd was also unable to resist locating the Aborigines within a crude evolutionary framework. In an unpublished autobiographical piece written in the 1880s, he had put in the mouth of a character obviously based on himself the view that there was as great a difference between the Caucasian and the Australian black as there was between the latter and the gorilla' ${ }^{58} \mathrm{O}^{\prime}$ Dowd was unable to account for the presence of the Aborigines, except as some dross subsequently thrown up by a strange continent:

The wretched horde whom Europe's host

In this strange land found

Are but the flotsam of our coast

Mere exudations from the ground. ${ }^{59}$

54. Advance Australia, 1 June 1897. For the theory that Aboriginal people were related to the Caucasians, see McGregor 1996.

55. Grey 1841: 263. See also Healy 1978b: 312-13.

56. Advance Australia, 1 June 1897.

57. Haynes 1998: 26.

58. Bernard O'Dowd, 'The Tutor', unpublished manuscript, nd [c1885] in O'Dowd Papers, Box 2/ 6, State Library of Victoria (VSL). 
By the late 1890 s, probably as a consequence of his reading of the report of the Horn Expedition and the early work of Spencer and Gillen, he had modified his attitude, but something rather stronger than mere traces remained. On the contrary, the older attitude is sharply refracted by the Lemurian myth, as when O'Dowd asked whether 'our dirty black brother' is 'the sole relic of an Atlantean civilisation, which, weighed in the balance and found wanting, had paid the price of extinction, by some great divine tide, for the abuse of its holy trust?'. O'Dowd places Aboriginality at the disposal of the colonial culture: here was 'a piece of the past on which to build epics and comic stories' ${ }^{60}$

In his study of colonial popular fiction, Robert Dixon has suggested that there was acute anxiety at the heart of Australian colonialism, a fear 'when Englishness is lost there is nothing to replace it; that in Australia, nation, like the interior of the continent, is a nameless blank'. Australia is thus condemned 'to a state of unstable hybridity - at once English and not English, and yet equally unable to be equated with those other, external identities which make readable its difference from Britain - Aborigines, Asia, the Pacific, Woman'. 'The lost race', in this scenario, becomes 'the unspeakable, unthinkable destiny of the national self' ${ }^{61}$ According to Docker, '[t] he tale of a lost white civilisation ... is not necessarily comforting' for Europeans, as '[i]t can suggest the instability of all civilisations in history ... there is no guarantee of permanency and superiority for present white society'. ${ }^{62}$ The only short story O'Dowd published - 'The City of Tramps' (1897) - dealt with such a lost race. In this Gothic tale, O'Dowd wrote about the strange rituals of an army of outcasts assembled in the Australian outback. The desert, in this story, is a threatening place: the Southern Cross glares at our hero 'like evil eyes', and he encounters all manner of 'deadbeats' in the heart of the continent, 'male, female and sexless'. The latter assemble in an encampment - a lost tribe of 'social outcasts - and their dress and conduct clearly announce their barbaric or 'native' status: 'They were nearly all in rags, but arranged with some attempts at gala dress - gum leaves and desert flowers, and crowns of spinifex being common.' They carried an old one-eyed man on their shoulders, and sang 'Our Wild Australian King', which was 'plentifully interspersed with 'crimson' accentuations', and had 'a fiendishly brutal and indelicate refrain at the end of each line'. At the end of this procession, the 'king' gave his speech from the throne, which was

a wild defiance of civilisation, a hiss of hate against the selfish happy settled folk of the world, a rallying call to the cornered rats of human society, an appeal to the basic anti-religious, anti-moral, anti-social emotions of his hearers, a flaring torch applied to their rebellion against control, to their wildest passions, a call to war, and a promise of spoils.

The author describes a wild orgy, which commenced when a band of naked Aboriginal women appeared on the scene. Poles were erected and covered in gum leaves, and a song and a dance occurred 'to the frantic delight of the assemblage'. When the Aboriginal women had stripped off all the gum leaves and thus completed the dance 'the king

59. Bernard O'Dowd, 'A Synod of Australia's Olympus; Scene - The summit of Chamber's Pillar; Time - Sunset. Midsummer; Enter the Muse of Australia', loose sheet, nd [c1887], in exercise book, O'Dowd Papers, Box 2/7, VSL.

60. Advance Australia, 1 June 1897.

61. Dixon 1995: 72, 198, 64 .

62. Docker 1991: 171. 
distributed these black diamonds among between 20 and 30 seemingly appreciative dead-beats'. Then, an actress and black-and-white artist mounted a boulder and sang 'The Sweater's Song', which was a prologue to 'Canonisation of the Sweater'. This involved lay figures dressing up so that they represented 'several notable members of the Legislative Council, a well-known ex-Mayor of Melbourne, a few Assembly members, several notorious factory owners and factory go betweens, many directors of squatting companies, heads of State departments, and quite a number of Governmenthouse people of all the colonies'. Other lay figures, representing their families, sat at their feet, while female members of the 'Tramp City' represented their women-folk. Then, at a signal from the king, the whole assemblage went along the line, knocking down the lay figures, then spitting on them, and finally going through the form of mutilating them. There were many more ceremonies, and the observer was forced to flee when it became clear that he had been designated as the human sacrifice for the night because of his own and his family's past sins against the tramps. ${ }^{63}$

In this tale, white colonial society's reversion to barbarism is understood as 'going native'; the dregs of society behave like savages. As Andrew Lattas has remarked, Australian intellectuals have constructed 'the primitive as that archaic possibility of humanity which threatens claims to modernity or civilisation' ${ }^{64}$ The equation of western civilisation's descent into barbarism with Aboriginality is also the theme of O'Dowd's 'Land of the "Terrible Rite"' (1897). ${ }^{65}$ In this poem, as in 'The City of Tramps', the desert is a hellish place, a fitting stage for the performance of 'barbaric' practices:

Its scanty niches hold a race

With brand of Desolation burned,

On whom, mayhap, in primal days

The 'evil eye' of God was turned.

O'Dowd's subject is the ritual of subincision as performed on and by Aboriginal men which, following RB Smyth and EM Curr, he believed to have a contraceptive function: ${ }^{66}$

They rob the Fate-accursed boy,

Who flinches while its tortures vex,

Of all but merest dregs of joy,

Of Holy Plenitude of Sex.

Can a Tyrian Moses have ushered a race

To that Canaan of Horror and Night?

Have remains of the frenzies Adonic a place

In this savage Malthusian blight?

63. Tocsin, 23 December 1897.

64. Lattas 1992: 47.

65. Tocsin, 4 November 1897.

66. Curr remarks that the real purpose of 'the terrible rite' was 'to destroy the power of begetting children'. See Curr 1886: 72. 
Does a Carthage atone for the breach of a trust

In the plutocrat days of its might,

With its women reserved as a latrine for Iust,

And its men for the 'Terrible Rite'?

The poet's speculation here is again informed by the lost race convention and the idea of reincarnation: the practices of the Aborigines are linked to the fate of Carthage, which is assumed to have perished as a consequence of its barbarity. The Aborigines are in his view relics of the past, atoning for the sins of the past, but their fate also contains a lesson for white colonial society, the 'alien races in this land' (a choice of phrase that surely underlines O'Dowd's uncertainty about the future of the white race in Australia). In O'Dowd's view, it too is barbarous, with its extremes of wealth and want, its 'harlot cities', and its sweaters' dens. The result is national and racial decline:

Its ogres rob the ripening maid

Of power to gift the world with men.

With Helot joys and scanty crust,

Its Youth drifts on to middle life,

Supplied with outlets for his lust,

But daring not to love a wife.

And 'mid its wildernesses, lo!

Its bands of wifeless men migrate,

With heavy swags of wearing woe

And souring billies full of hate

There is no romanticisation of the 'noble bushman' here; instead, he is a victim of modern capitalism, which threatens to inflict on him and other victims of competitive greed the kind of fate suffered by the central Australian Aborigines:

While the millstones of Mammon continue to grind,

And Injustice's locusts to blight,

Can we feel that to savage alone is confined

The disgrace of the 'Terrible Rite'?

Ev'ry person, succumbing in childless despair

In our brutal competitive fight,

Is a victim our hypocrite apathies tear

With the flints of a 'Terrible Rite.'

The lost race is a 'hybrid' with an 'ambivalent racial and cultural identity' ${ }^{67}$ colonial capitalism was creating a kind of 'half-caste' tribe - white in its skin colour but black

67. Dixon 1995: 63. 
(in every sense of the word) in its character, and therefore liable to descend to the level of degradation depicted in 'The City of Tramps'. The representations of Aboriginal society contained in the writings of Curr, Smyth, Spencer and Gillen provided O'Dowd with the materials for an image of the (white/black) 'mob', the kind of barbarism likely to result from the free play of capitalist greed, and (what was for him as well as many other socialists its natural and alarming corollary) racial decline. This is something like the dystopianism of HG Wells, but with a colonial twist.

In 1903, when AG Stephens came to consider "The Land of the "Terrible Rite" for republication in O'Dowd's first book of poetry (it appeared first in the radical weekly, the Tocsin), he was concerned about O'Dowd's understanding of the purposes of subincision. As there was 'a matter of scientific fact' at stake, he told O'Dowd, the poem 'must accord with the best theory - i.e., must respect Truth. A myth wd. be different. In Curr's day, your verse would have bn. right; but, since we have passed his day, your verse shd. move with the knowledge of the time you write $\mathrm{in}^{\prime}{ }^{68} \mathrm{O}^{\prime}$ Dowd replied that he was aware before writing the poem that there were conflicting theories about the purpose of the practice, but he 'was not pretending to write an exact treatise', and so believed he 'had the right to adopt Curr's theory for my vatic purpose'. ${ }^{69}$ The report of the Horm Scientific Expedition to central Australia was published in the year before 'The City of Tramps' and 'The Land of the "Terrible Rite"' appeared, and it is likely that both pieces were informed by O'Dowd's reading of it. There is a vivid description by Gillen of the practice of subincision among the central Australian Aborigines in the Horn volume on anthropology but O'Dowd's problem, at least in Stephens' eyes, was that in the same volume EC Stirling had expressed considerable scepticism about Curr's theory of a 'Malthusian' purpose underlying subincision. ${ }^{70}$ Spencer and Gillen similarly rejected the idea in their Native tribes of central Australia (1899), declaring that 'the Arunta natives at least have no idea of its having been instituted with the idea of its preventing or even checking procreation'. 71

O'Dowd, however, was less concerned with anthropological accuracy or Aboriginal people's ownership of their own culture than prophecy, and, with many of his contemporaries, he sensed that western civilisation was in decline. The spread of contraception and declining birth rates were, for $O^{\prime}$ Dowd and many others, among the most compelling evidence of this degeneration, and so Curr's theory permitted him to hang a critique of colonial civilisation on to a convenient Aboriginal peg. What he regarded as the degradation of the central Australian Aborigines foreshadowed the fate of white colonial society. Heavily influenced by Social Darwinism and theosophy, he was also inclined to regard history as cyclical, a story of the rise, decline and fall of great races and civilisations, who ultimately pay the price for their errant ways. O'Dowd saw both white colonial society and Aboriginal society in this light, with the lost race convention and the doctrine of reincarnation providing the linchpin. Aboriginal society

68. AG Stephens to O'Dowd, 11 March 1903, NLA MS 273.

69. O'Dowd to Stephens, 16 March 1903, Box 1/8, VSL. In the collection Dawnward? (1903), there is a poem with the title 'The Seed Time' that employs some of the material from 'The Land of the "Terrible Rite"' but all references to the Aborigines have been removed. Stephens' opinions prevailed. See Anderson 1969: 46-9 for a comparison of the two poems.

70. Stirling 1994: 33-4.

71. Spencer \& Gillen 1938: 263-5. 
was paying the price for the past sins of some dead and forgotten civilisation of which it was probably a remnant; European colonial society might yet find itself similarly degraded unless it mends its ways. For O'Dowd, central Australian Aboriginal society is European Australia's degraded 'other', a linguistic strategy that was integral to his attempt to project a utopian nationalist vision for the consumption and inspiration of European colonists. Greg Dening has remarked that 'there is no other that I describe that is not joined to myself'. ${ }^{72}$ There was similarly no nationalist utopia for white Australians without an Aboriginal 'other' somewhere near its core.

O'Dowd also employed an 'Aboriginal' theme on the only occasion he turned his hand to drama. The scene was Mount William, the site of the great greenstone hatchet head quarry of the Woiwurrung groups of the Lancefield/Mount Macedon area in Victoria. It is fitting that he should have chosen this setting for his play since, as Isabel McBryde has shown, Mount William had a significant place in the late colonial ethnographic imagination in southeastern Australia. White scholars and antiquarians were interested in the site around the turn of the century and even agitated for its preservation but their sentiments, according to McBryde, were 'largely rooted in ... Social Darwinism'. They 'recognized the importance of Aboriginal culture, but not any continuing active involvement of its holders in its study or recording once "contaminated" by contact with European civilization'. Aboriginal people consequently 'remained passive "subjects". 73

O'Dowd's play, to be called 'The Wooden Churinga', was intended as 'a modern version of the struggle of Paul and the other Apostles against the idol-makers of Ephesus with their rebellious cry: 'Great is Diana of the Ephesians'. The vested interests there objected to a New Churinga, which was wooden and in the shape of a cross, and 'guaranteed by a distant \& great medicine man to be the sole method of saving the world'. A conflict ensued between defenders of the old stone churingas and proponents of the new: the climax was the 'final impaling [on his own churinga] of the medicine man, after a howling mob for economic as well as religious reasons had paraded Mt William crying 'Give us Barabbas' and 'Great is the Churinga of antiquity'. 'Unfortunately, I'm not built dramatically', O'Dowd explained, '\& the first speech of the ambassador took so many pages that $l$ gave the thing up before reaching the dialogue stage' ${ }^{74}$ We should perhaps be grateful for small mercies: but again the message seems clear. The Aborigines who remain attached to their traditional culture, here symbolised by the stone churinga, are barbaric: they stand in the way of civilisation and progress. The medicine man, who tries to convince them of the transforming power of the cross, is himself crucified. The Aborigines, who have rejected Christ, are destined to remain primitive and unenlightened.

There was considerable ambivalence in O'Dowd's attitudes to the Aborigines. On the one hand, the complexity of the central Australian Aborigines' customs fascinated and impressed him, which might well provide some support for Morphy's position in

72. Dening 1988: 66 .

73. McBryde 1995: 9-10. For further details, see Howitt 1996: 311-12; McBryde 1984: 267-85.

74. O'Dowd to N. Higgins, 17 February 1914, Palmer Papers, NLA MS 1174/1/1036; Victor Kennedy, 'O'Dowd biography VK's notes \& draft', nd p. 60, Victor Kennedy Papers, MS 9419/ 2044-2098, VSL. 
his controversy with Wolfe, reviewed earlier in this article. O'Dowd pointed out that ' $[t]$ he fact that marriage relations are regulated in a much more effectual manner than we manage these things ourselves, and that elaborate automatic machinery against in-breeding have been handed down from immemorial times, cause us some astonishment when we remember that we call these aborigines the "lowest" of the human race'. ODowd's recognition of the complexity of Aboriginal customs seems to foreshadow sympathy and understanding. He was particularly impressed by Aboriginal mythology:

And those strange myths of the Alcheringa (the dim past, the dream times) with their sable Odysseys, their singular ceremonial records, so reminiscent of the great Confucian book of ceremonies and rituals nearer home, their prescient (or is it reminiscent?) consciousness of the Darwinian evolutionary hypothesis of the origin of man, their stocks and stones which seem to carry us back to Chaldean plains and jealous gods of other races, and the strange sadness, fitting atmosphere of any record of the history of the human race, that floats over and in and through them all, and which overpowers even the reader of them! ${ }^{75}$

Indeed, at times $\mathrm{O}^{\prime}$ Dowd spurned conventional colonial wisdom about the Aborigines, as in his poem 'Democratize the World', which was first published in the Socialist in 1907. Here, the poet rejected the idea that colonial democracy ought to be confined to the Europeans. If it has any reality, democracy must encompass all:

The race that claims within its bound

Divine Equality,

And treads another on the ground.

Is building on a lie.

You weak and outcast of our own,

We sadly hear your plea,

Nor rest till you and all have grown

To manhood, equal, free:

But if the tale we daily hear

Too glibly from each tongue,

Of races doomed to disappear,

Of tribes whose songs are sung,

Is based on cosmic law of Good,

You too our sad ones must

Renounce the Hope of Brotherhood

And be to serfdom thrust. ${ }^{76}$

75. Tocsin, 7 September 1899. For the melancholy theme in European representations of Aboriginal people, see McLean 1998: 18-33, 49-51.

76. O'Dowd 1944: 181-2 (first published in Socialist, 1 June 1907). 
Here was a vision of the oneness of humanity, which could even sustain a scepticism about the popular 'doomed race' theory. If the Aboriginal race was destined to disappear, argued O'Dowd, so was the most oppressed class in white colonial society - the working class - for its claims to justice could only rest on the same foundations as those of the Aborigines: common humanity. His ideal of democracy upheld the rights of all, irrespective of class, race and sex. At his most doctrinaire (and, from a late twentieth century perspective, most attractive), $O^{\prime}$ Dowd opposed the White Australia policy and rejected racial privilege in any form. 77

O'Dowd's attitude to Asia warrants separate treatment, but it must also be considered in any examination of his attitude to Aboriginal Australians. As a young man, O'Dowd's racial views seem to have been fairly conventional, but by the late 1890 s, were somewhat unusual by the standards of his day. He opposed the White Australia policy, arguing instead for 'universal brotherhood, irrespective of race, creed, sex, caste or colour'. He rejected as totally unscientific the attempt to demonstrate the inferiority of certain races, including the Australian Aborigines, by reference to such factors as skull shape. ${ }^{78} \mathrm{O}^{\prime}$ Dowd attributed his transformation, in part, to his reading of Confucius and Mencius, which left him with the impression that he was 'reading about peoples \& ways of thought \& institutions that I had once actually lived among, used and adhered to', so that all his old repulsion of Chinese disappeared, leaving him a 'democrat'; while his attitude to 'the Hindoo' changed after a series of psychic experiences in which, against his will, he was changed into 'a prodigious female Raksha hating but at the mercy of a male Raksha who delighted in the works of evil which I too had to seem to do but loathed to do'. The mental discipline involved in this business gave O'Dowd 'an insight into the mystery of evil which I never had before, \& which makes me very tolerant since'. ${ }^{79} \mathrm{O}^{\prime}$ Dowd also distinguished between different races. He told Nettie Palmer in 1915 that he did not 'happen to like the Jap soul much' but liked 'the Chinese very much' and went as far as to advocate 'a judicious mixture' with both the Chinese and the Afghans. ${ }^{80}$

The most significant influence in the formulation of these racial attitudes was possibly the Theosophical Society, a point hinted at by his reference to reincarnation, and his suggestion of a new racial mix in Australia, which might have owed something to the theosophists' interest in the evolution of a 'New Race'. Despite Blavatsky's views on Aborigines, the Theosophical Society preached universal brotherhood, which had much in common with $\mathrm{O}^{\prime}$ Dowd's ideal of 'colour-blind' democracy. ${ }^{81} \mathrm{O}^{\prime}$ Dowd, however, was probably indebted to theosophical racial theory in other ways. Literary critics and cultural historians have often drawn attention to O'Dowd's vision of Australia as 'Delos of a coming Sun-God's race' in his poem 'Australia' without considering the possibility of a theosophical inspiration for the idea. It has instead been located within the colonial discourses of the 'Coming Man', which is reasonable so far as it goes, but somewhat imprecise. CW Leadbeater, the theosophical author and leader whom O'Dowd heard

\footnotetext{
77. See Tocsin, 25 April 1901.

78. Theosophy in Australasia, 2 September 1912, 1 October 1912: 153, 176.

79. O'Dowd to M Pitt, 22 October 1907, Pitt Papers, JK Moir Collection, Box 22A/1(a), VSL.

80. O'Dowd to N Palmer, 10 January 1915, Palmer Papers, NLA MS 1174/1/1371.

81. Roe 1986: xii, 115.
} 
speak during the former's visit to Australia in 1905, believed Australia to be the 'home of a new sub-race' of the Aryans who would possess much greater powers of intuition and synthesis than their predecessors. ${ }^{82}$ Blavatsky, as we have seen, also believed that the infusion of fresh races into the Australian continent might lead to 'new forms'. So at the very least, O'Dowd's theosophical connections must be considered to form a part of the intellectual background for the poem. There is, however, other evidence in O'Dowd's writings that he was influenced by Blavatsky's root-race theory. In The Bush, there are references to the doctrine of the Great Year, which $\mathrm{O}^{\prime}$ Dowd derived from his reading of Plutarch and recognised as similar to the theosophical root-race theory. ${ }^{83}$ In a paper with the title 'Race Prejudice', which he published in the Society's journal in 1912, he discussed

the transitory nature of human glory and the inevitableness of decay ... the ... contemporaneous existence of races in the first flush of their springtime bloom, races in the full vigour of their culminant accomplishments, races in the peace of decline, and races in the awful winter of death waiting the fateful moment when their new birth-hour, the springtime of their next Great Year, will be sounded.

There can be little doubt where he placed the Australian Aborigines in this scheme of things. Yet, for O'Dowd, the cosmic law of love transcended the rise and fall of civilisations. It proclaimed human brotherhood, the highest truth that all races were really one. All progress in human affairs ultimately depended on the strength of the note of rebellion against the 'sombre song of Fate'. ${ }^{84}$

\section{Conclusion}

O'Dowd was unusual in his opposition to the White Australia policy, but the complexity of his racial views should act as a warning to historians who wish to ransack the past for examples of 'racism'. What this article has shown is that his attitudes to race - and to Australia's Indigenous people in particular - were marked by complexity and ambivalence. The categories 'racist' and 'anti-racist', 'enlightened' and 'unenlightened', have only limited usefulness in such a historical account: as Dening has suggested, we need to resist the temptation to accommodate the knowledge of people of the past to our own, and thus neutralise its 'otherness'. ${ }^{85}$ Humphrey McQueen's comment in 1970 that '[r]acism was the most important single component of Australian nationalism' was not so much wrong as imprecise. ${ }^{86} \mathrm{McQueen}$ failed to recognise the complexity of racial ideas among the colonists. Historians of racial attitudes in Australia face the difficult task of urtangling the diverse influences that shaped attitudes to race in Australia, including in their accounts some consideration of the ways in which European ideas were received and adapted in an antipodean colonial context. In this article, I have stressed the influence of theosophy on O'Dowd, but to identify such influences is insufficient: we must also to be attentive to the ways in which theosophical ideas found colonial expression. The Lemurian fantasy, for example, did not originate in the colonies, but it met certain needs of the colonisers, providing some 'enterprising' spirits with

82. Roe 1986: 216; Drury and Tillett 1980: 11-12; Leadbeater 1915.

83. See Trompf 1979: 11-12, 61-2, 67, 76, 201-2.

84. Theosophy in Australasia, 2 September 1912: 155-6.

85. Dening 1992: 339-67.

86. McQueen 1985 [1970]: 29. 
material they needed for their 'land rites'. In general, the attitudes of some radicalnationalist intellectuals to Aborigines (and we have noticed similar developments in New Zealand) were marked by a preoccupation with 'history-making', with filling up the 'blank spaces' of the antipodean landscape and the colonial mindscape with 'indigenous' myths, legends and a useable past. An antipodean counterpart of King Arthur was required - or, as O'Dowd would have it, a Homer in the gum trees.

If this preoccupation had been peculiar to O'Dowd, it might now be treated indulgently as yet another eccentricity of an eccentric man. If it were a phenomenon that had ended in colonial times - if there had been some point at which the process of national becoming concluded - the contemporary relevance of the themes explored in this article would be harder to define. There is, however, no such termination point. A preoccupation with 'future pasts' is part of the Australian postcolonial condition. ${ }^{87} \mathrm{O}^{\prime}$ Dowd, who was fascinated by the relationships between present and past, self and other, would have enjoyed this paradox of imagined futures that always require us to bend back to the past, to come to terms with colonial origins.

\section{Acknowledgments}

My thanks to the Australian Research Council for supporting this research, and Dr Nicole McLennan, Dr Gordon Briscoe and Professor Isabel McBryde for their helpful comments.

\section{References}

Albinski, Nan, 1987. 'Visions of the nineties.' Joumal of Australian Studies 20 (May): 1222.

Anderson, Hugh, 1969. The poet militant: Bernard O'Dowd. Melbourne.

Attwood, Bain, 1992. 'Introduction', in Bain Attwood and John Arnold (eds) Power, knowledge and Aborigines. Special edition of Journal of Australian Studies, Melbourne, pp i-xvi.

Attwood, Bain, 1996. 'Making history, imagining Aborigines and Australia', in Tim Bonyhady and Tom Griffiths (eds) Prehistory to politics: John Mulvaney, the humanities and the public intellectual. Carlton, pp 98-116.

Blavatsky, HP, 1993. The secret doctrine vol. II. Adyar, Madras.

Byrne, Denis, 1996. 'Deep nation: Australia's acquisition of an indigenous past.' Aboriginal History 20: 82-106.

Carter, David, 1994. 'Future pasts', in David Headon, Joy Hooton and Donald Horne (eds) The abundant culture: meaning and significance in everyday Australia. St Leonards (NSW), pp 3-15.

Curr, Edward M, 1886. The Australian race: its origin, languages, customs, place of landing in Australia, and the routes by which it spread itself over that continent, volume I. Melbourne.

Dening, Greg, 1988. The Bounty: an ethnographic history. Melbourne.

87. Carter 1994. 
Dening, Greg, 1992. Mr Bligh's bad language: passion, power and theatre on the Bounty. Cambridge.

Dixon, Robert, 1995. Writing the colonial adventure: race, gender and nation in Anglo-Australian popular fiction, 1875-1914. Melbourne.

Docker, John, 1991. The nervous nineties: Australian cultural life in the 1890s. Melbourne.

Drury, Nevill and Tillett, Gregory, 1980. Other temples, other gods. Sydney.

Elliott, Brian, 1967. The landscape of Australian poetry. Melbourne.

Elliott, Brian, 1977. 'Jindyworobaks and Aborigines.' Australian Literary Studies 8(1) May: 29-51.

Elliott, Brian, 1979. 'Introduction', in Brian Elliot (ed.) The Jindyworobaks, St. Lucia, pp xvii-Ixvi.

Grey, George, 1841. Journals of two expeditions of discovery in north-west and western Australia during the years 1837, 38, and 39, under the authority of Her Majesty's Government. Describing many newly discovered, important, and fertile districts, with observations on the moral and physical condition of the Aboriginal inhabitants, Ec.Ec., vol.1. London.

Griffiths, Tom, 1996a. Hunters and collectors: the antiquarian imagination in Australia. Melbourne.

Griffiths, Tom, 1996b. 'The social and intellectual context of the 1890s', in Morton and Mulvaney (1996), pp 13-18.

Hamilton, Annette, 1990. 'Fear and desire: Aborigines, Asians and the national imaginary', in David Walker (ed.) Australian perceptions of Asia: Australian Cultural History no. 9, pp 14-35.

Haynes, Roslynn D, 1998. Seeking the centre: the Australian desert in literature, art and film. Cambridge.

Healy, II, 1978a. Literature and the Aborigine in Australia 1770-1975. St Lucia.

Healy, JJ, 1978b. 'The Lemurian nineties'. Australian Literary Studies 8(3), May: 307-16.

Hill, Barry, 1996. 'Through Larapinta land: Baldwin Spencer's glass case', in Morton and Mulvaney (1996), pp 31-41.

Horn, WA, 1994 (first published 1896). 'Introduction' in Baldwin Spencer (ed.) Report on the work of the Horn Scientific Expedition to central Australia: Part I. Introduction, narrative, summary of results, supplement to zoological report, map. Bundaberg (Qld).

Howe, KR, 1991. Singer in a songless land: a life of Edward Tregear 1846-1931. Auckland.

Howitt, AW, 1996 (first published 1904). The native tribes of south-east Australia, Canberra.

Kennedy, Victor and Palmer, Nettie, 1954. Bemard O'Dowd. Carlton.

Knight, Stephen, 1991. The selling of the Australian mind: from First Fleet to third Mercedes. Port Melbourne.

Lattas, Andrew, 1992. 'Primitivism, nationalism and individualism in Australian popular culture', in Bain Attwood and John Arnold (eds), Power, knowledge and Aborigines, Special edition of Joumal of Australian Studies, Melbourne, pp 45-58.

Leadbeater, CW, 1915. Australia and New Zealand as the home of a new sub-race. Sydney.

Macintyre, Stuart, 1998. 'Imperial history', in Graeme Davison, John Hirst and Stuart Macintyre (eds), The Oxford companion to Australian history, Melbourne, pp 339-40. 
McBryde, Isabel, 1984. 'Kulin greenstone quarries: the social contexts of production and distribution for the Mt William site'. World Archaeology 16(2): 267-85.

McBryde, Isabel, 1995. 'Dream the impossible dream? Shared heritage, shared values, or shared understanding of disparate values?' Historic Environment 11(2\&3): 8-14.

McGregor, Russell, 1996. 'An Aboriginal Caucasian: some uses for racial kinship in early twentieth century Australia.' no. 1. Australian Aboriginal Studies: 11-20.

McLean, Ian, 1998. White Aborigines: identity politics in Australian art. Cambridge.

McQueen, Humphrey, 1985 [1970]. A new Britannia: an argument concerning the social origins of Australian radicalism and nationalism. Ringwood.

Morphy, Howard, 1996. 'Empiricism to metaphysics: in defence of the concept of the Dreamtime', in Tim Bonyhady and Tom Griffiths (eds), Prehistory to politics: John Mulvaney, the humanities and the public intellectual. Carlton, pp 163-89.

Morton, SR and Mulvaney, DJ (eds), 1996, Exploring central Australia: society, the environment and the 1894 Horn Expedition. Chipping Norton (NSW).

Mulvaney, DJ and Calaby, JH, 1985. 'So Much That Is New'. Baldwin Spencer, 1860-1929: a biography. Carlton.

O'Dowd, Bernard (Danton), 1897 (4 November). 'The Land of the "Terrible Rite"'. Toc$\sin , \mathrm{p} 1$.

O'Dowd, Bernard (Gavah the Blacksmith), 1897 (23 December). 'The City of Tramps: a "Tocsin" Romance'. Tocsin; $\mathbf{p} 6$.

O'Dowd, Bernard (Gavah the Blacksmith), 1899 (7 September). 'Central Australian Aborigines'. Tocsin, $\mathrm{p} 3$.

O'Dowd, Bernard (Gavah the Blacksmith), 1901 (25 April). 'White Australia and qualified democracy'. Tocsin, $\mathrm{p} 4$.

O'Dowd, Bernard, 1912 (2 September, 1:October). 'Race prejudice'. Theosophy in Australasia, pp 153-6, 175-9.

O'Dowd, Bernard, 1944. The poems of Bernard O'Dowd: collected edition. Melbourne.

Osborne, Graeme, 1978. 'A socialist dilemma', in Ann Curthoys and Andrew Markus (eds) Who are our enemies? Racism and the working class in Australia. Sydney, pp 11228.

Roe, Jill, 1986. Beyond belief: theosophy in Australia 1879-1939. Kensington.

Scates, Bruce, 1997. 'We are not ... [A]boriginal ... we are Australian': William Lane, racism and the construction of Aboriginality'. Labour History 72 (May): 35-49.

Sellick, Robert, 1995. 'The Jindyworobaks and Aboriginality', in Philip Butterss (ed.), Southwords: essays on South Australian writing. Kent Town (SA), pp 102-15.

Smith, Anthony D, 1989. 'The origins of nations'. Ethnic and Racial Studies 12(3) July: 340-67.

Smyth, R Brough, 1972 (first published 1878). The Aborigines of Victoria: with notes relating to the habits of the natives of other parts of Australia and Tasmania Compiled from various sources for the Government of Victoria. Melbourne.

Spence, Lewis, 1932. The problem of Lemuria: the sunken continent of the Pacific. London. 
Spencer, Baldwin, 1994 (first published 1896). 'Through Larapinta land: a narrative of the Horn Expedition to central Australia', in Baldwin Spencer (ed.), Report on the work of the Horn Scientific Expedition to central Australia: Part I. Introduction, narrative, summary of results, supplement to zoological report, map. Bundaberg (QId).

Spencer, Baldwin and Gillen, FJ, 1938 (first published 1899). The native tribes of central Australia. London.

Stirling, EC, 1994 (first published 1896). 'Anthropology', in Baldwin Spencer (ed.) Report on the work of the Horn Scientific Expedition to central Australia: Part IV Anthropology. Bundaberg (Qld).

Trompf, GW, 1979. The idea of historical recurrence in Westem thought: from antiquity to the Reformation. Berkeley and Los Angeles.

Tsokhas, Kosmas, 1998. 'Romanticism, Aboriginality and national identity: the poetry and prose of Mary Gilmore'. Australian Historical Studies 29(111), Oct: 230-47.

Wolfe, Patrick, 1991. 'On being woken up: the Dreamtime in anthropology and in Australian settler culture.' Comparative Studies in Society and History: An International Quarterly 33(2) April: 197-224. 